\title{
HUELLAS DE LA FOTOGRAFÍA EN LA NARRATIVA DE MAXIMILIANO BARRIENTOS: UNA APROXIMACIÓN
}

\author{
Alba Diz Villanueva \\ Universidad Complutense de Madrid \\ Madrid, España \\ albadiz@ucm.es
}

\section{RESUMEN / ABSTRACT}

El objetivo del presente trabajo es poner de relieve la importancia e influencia de la fotografía en la narrativa del escritor boliviano Maximiliano Barrientos. Se analizan las diferentes funciones que esta desempeña tanto a nivel argumental como de estilo en sus textos, principalmente en el volumen de relatos Fotos tuyas cuando empiezas a envejecer. Asimismo, el artículo focaliza en la reflexión que se produce en algunos textos de Barrientos en torno a la capacidad de la fotografía, del arte y de la literatura para registrar las experiencias y salvaguardarlas del paso del tiempo.

PalABRAS Clave: fotografía, narrativa, Maximiliano Barrientos, reflexión metaliteraria y meta-artística.

\section{PHOTOGRAPHY'S TRACES IN MAXIMILIANO BARRIENTO'S NARRATIVE: AN APPROXIMATION}

The aim of this paper is to highlight the relevance and the influence of photography in the narrative of the Bolivian writer Maximiliano Barrientos. This work analyzes the main functions that photography plays in his texts, both in the story line and in the narrative style, mostly in the volume of short stories Fotos tuyas cuando empiezas a envejecer. Furthermore, this paper focuses on the reflection on the ability of photography, art and literature to record experiences and to save them from passing of time.

KEYWORDS: Photography, narrative, Maximiliano Barrientos, meta-artistic and metaliterary reflection. 


\section{INTRODUCCIÓN}

La relación entre literatura y fotografía -que se enmarca, de acuerdo con Ansón ("Fotografía..." 4), en la relación, más general, entre palabra e imagen ${ }^{1}-$ ha conocido, desde la invención del daguerrotipo, muy diversas formas y, como ha señalado la crítica, prolíficas muchas de ellas. El citado estudioso, tras realizar un repaso por la presencia de la fotografía en la literatura escrita en español desde finales del siglo XIX hasta comienzos del siglo XXI, constata la notoria influencia que este arte ha ejercido y ejerce en las letras, presente como tema o motivo argumental, pero determinante también desde el punto de vista formal, en el desarrollo de técnicas narrativas y descriptivas e, incluso, desde el punto de vista genérico, en el surgimiento de nuevos moldes:

Buena parte de los aspectos que caracterizan la forma y el fondo de la narrativa moderna, entendiendo que la modernidad literaria empieza en el último cuarto del siglo XIX con la reacción de la estética simbolista y decadente en Francia ante la hegemonía del realismo, no pueden ser explicados sin tener en cuenta las mutaciones que la fotografía introdujo en el mundo del arte y de la literatura. Los antihéroes, el monólogo, la narración subjetiva y en presente, el nacimiento del poema en prosa como género literario, la vida cotidiana y anónima como argumento, la fragmentación del texto son aspectos, entre otros muchos, que han de entenderse desde una perspectiva fotográfica. De otro modo, estaríamos pasando por alto uno de los fenómenos comunicativos más influyentes y decisivos de nuestro tiempo (Ansón "Influencia..." 159).

A todas estas transformaciones y, en concreto, a la aparición de vertientes literarias, Mercedes López Suárez añade la panorámica en Francia o costumbrista en el ámbito español, que, "ambientadas en el paisaje urbano donde se acogen las diferentes tipologías humanas que lo habitan”, se nutren de un interés científico, "por esa vena «fisiológica» que instaba a pintar costumbres, formas

1 La relación entre imagen y escritura da lugar, como señalan Carriedo y Reboul (9-10), a interacciones mutuas diversas y productivas (donde entran en juego multitud de resonancias semióticas, simbólicas, estéticas e ideológicas), no exentas de tensión en algunos casos. Ello evidencia la tendencia a la hibridación entre las distintas disciplinas artísticas, a la porosidad cada vez más notoria que existe entre la literatura y la fotografía, el cine, la pintura, el dibujo, etc. 
de vida, curiosidades urbanas, retratos de sus tipos realizados con la mayor objetividad, respondiendo a la verdad de lo real" (104). También en el ámbito de la narrativa, la fotografía propició la literatura del realismo decimonónico, facilitó documentos fehacientes para la escritura de la novela naturalista y verista, fue empleada como dispositivo narrativo para libros de memorias, al tiempo que ha servido de base a técnicas de narración impersonal (López Suárez 112). Tal es la repercusión de la fotografía sobre la literatura que su irrupción marcaría, en opinión de Cunningham, Fisher y Mays, una etapa en su historia: "While the historical eruption of the photograph is, for obvious reasons, assumed to be a part of the history of the visual arts, centred around painting, there is much to suggest that it is equally crucial (and transformative) as a moment in literary history" (Cunningham et al. 5).

Por su parte, Olivier (432) reconoce, entre la pluralidad de "relaciones y realizaciones híbridas" que pueden establecerse entre ambas disciplinas artísticas...

la ilustración, en el sentido más literal del término, o sea, la efectiva inserción de reproducciones fotográficas entre las páginas de un libro que puede o no ser de ficción y las muy variadas formas de presencia-ausencia de la fotografía en un relato de ficción o un ensayo, vierta este o no sobre la propia fotografía. En efecto, se analiza de modo recurrente la notoria influencia del encuadre fotográfico en los modos narrativos, sobre todo a partir de la segunda mitad del siglo $\mathrm{XX}$, y asimismo, la elaboración de un relato a partir de una foto no reproducida y, en ocasiones, imaginaria.

Al respecto de este último aspecto señalado por la estudiosa, Carriedo y Reboul (10) apuntan que el dispositivo fotográfico puede determinar la configuración del texto desde distintos prismas (narrativo, indicial, metafórico, simbólico, documental) sin llegar a materializarse como imagen en el libro e, incluso, sin estar representado verbalmente a través del discurso descriptivo. Este es, de hecho, uno de los tres niveles que Montier (35) reconoce en la interacción entre literatura y fotografía ${ }^{2}$, aquel "des écrivains dans les œuvres desquels la photographie est absente matériellement tout en étant omnipresente, tant dans

2 En el contexto de esta interacción, el autor señala la necesidad de tratar ambas disciplinas de manera conjunta, mediante el concepto, "unifié et unifiant", de fotoliteratura (Montier 32). 
la construction de la fiction que dans le style même, le mot style étant entendu au sens proustien de ce qui est conçu comme une façon absolue de voir".

Ello resulta de interés al objeto de este trabajo, puesto que la narrativa del escritor boliviano Maximiliano Barrientos (Santa Cruz de la Sierra, 1979 ) encuentra en la fotografía un elemento estructural. En concreto, en su volumen de relatos Fotos tuyas cuando empiezas a envejecer (Editorial Periférica, 2011) - una versión revisada, corregida y adaptada del originario Los daños, publicado en el año 2006 por la editorial La Hoguera, en Boliviala presencia de la fotografía, detectable ya en el mismo título, determina en gran medida cada uno de los relatos, pues, además de aparecer como un motivo recurrente, actúa como nexo entre todos ellos y marca el ritmo y el estilo de la narración.

\section{LA FOTOGRAFÍA EN LA OBRA DE MAXIMILIANO BARRIENTOS}

Antes de examinar en profundidad esta obra y el rol que en ella desempeña la fotografía, conviene realizar una panorámica por la narrativa de Barrientos para evidenciar que se trata de un elemento transversal en el conjunto de sus textos, en los que desempeña diferentes funciones, desde constituirse como un componente con mayor o menor peso en la trama hasta desencadenar reflexiones acerca de la memoria o de la capacidad del arte para registrar o moldear las experiencias vividas.

En el relato "Gringo", incluido en el volumen Una casa en llamas (2015), se encuentra un ejemplo de representación discursiva de unas fotografías a las que el lector no accede sino a través de su descripción en la narración. La tía del narrador-protagonista recibe un sobre, procedente de Londres, con cinco fotos de extrema violencia, que retratan a su exmarido, un austríaco apodado Gringo, asesinando a una joven junto a otros tres hombres y participando en actos sexuales:

Al sacar las fotografías del sobre, constaté que eran cinco. En la primera aparecía Gringo, tendría los años que tuvo cuando se casó con mi tía. El pelo cortado al rape como si nunca hubiera abandonado el ejército, los ojos celestes y plásticos, sin vida. Lo acompañaban otros tres individuos y una muchacha de marcados rasgos indígenas, era casi una niña. Ella estaba desnuda, el pubis era incipiente, apenas una pelusa entre las piernas. En la segunda foto un hombre penetraba 
a la chica, Gringo se masturbaba observando el acto desde cerca. En la tercera, Gringo acuchillaba a la muchacha en el abdomen, los otros miraban. En la cuarta, la muchacha, un cadáver ya, estaba en el piso con múltiples heridas en el cuerpo y con la garganta degollada. Gringo, vistiendo lencería erótica de mujer, miraba a la cámara. Tenía una peluca negra que le llegaba a los hombros. En la quinta, Gringo era sodomizado por uno de los hombres, ya no se veía el cuerpo de la muchacha.

Cuando terminé de verlas, miré a mamá. Ya sin poder resistirlo, se puso a llorar.

¿Son reales?, dijo.

Las repasé otra vez y las oleadas de asco se concentraron en mi garganta. Era asco, por supuesto, pero también era rabia y un malestar alimentado por la sorpresa, algo parecido al asombro que acontecía en la infancia cuando veía algo diferente, cuando sabía que luego de aquello que había acontecido nunca más sería la misma persona de antes. Una sensación que creí perdida y que antes asociaba a la felicidad y que en ese momento, al revisar por tercera vez las fotografías, quedaría relacionada para siempre con lo abyecto (Barrientos, Una casa en llamas).

Como se puede apreciar, la representación o imagen que el lector se forma de estas fotografías procede, además de las descripciones, que por lo general en Barrientos nunca son pormenorizadas - pues, como ha señalado en una entrevista, estas ralentizan la narración y en consecuencia atentan contra la velocidad que busca en sus prosas ${ }^{3}$-, de las reacciones de los personajes al observarlas: asco y abyección en el caso del protagonista, nerviosismo, angustia y hasta malestar físico, en el caso de su madre y su tía. Se constata así el poder de la imagen, que, a pesar de la sobreexposición visual que según el propio autor caracteriza los tiempos presentes (Louzao), no se borra,

3 En una entrevista concedida a Ocultalit, señala el autor a este respecto: "Me interesa una narrativa centrada en la acción y no en la descripción. Me interesa la velocidad, y la descripción excesiva atenta contra eso, tiene una incidencia en el ritmo, lo enlentece. Además, en esta época tan visual en la que estamos bombardeados por imágenes, la descripción minuciosa resulta inútil. No podemos competir contra una valla publicitaria o contra una fotografía. Esa era la ambición del realismo en el siglo XIX, antes de que apareciera el cine. El cine obligó a narrar de otra forma, de lo contrario la literatura se volvería un arte obsoleto. Joyce, Faulkner, Woolf, y todo lo que conocemos como vanguardia se origina en esa búsqueda de nuevos modos de narrar una vez que el proyecto del realismo decimonónico fenece" (Louzao). 
permanece: "La imagen de Gringo asesinando a una muchacha iba a quedar para siempre en mi sistema" (Barrientos, Una casa en llamas).

La "investigación" que el protagonista emprende a petición de su madre pasa por intentar rescatar la época en que ese supuesto asesinato tuvo lugar, y los únicos testimonios materiales que se conservan de entonces son precisamente las fotografías. El protagonista recurre al álbum familiar, cuya contemplación desencadena a su vez otras imágenes, verídicas -al menos parcialmente- unas (los recuerdos), surgidas de la ebriedad, del sueño y de la alucinación, otras.

La acción del relato se centrará en conocer la veracidad de estos documentos visuales enviados de forma anónima: ¿son auténticos o son un montaje? Para averiguarlo, el protagonista recurre a un antiguo compañero fotógrafo. El examen de las imágenes, que provoca en este personaje emociones similares de rechazo, no deja lugar a dudas: son reales. La brutalidad de esas fotografías y el carácter fehaciente que se les atribuye (probada la autenticidad del material, en ningún momento se cuestiona la veracidad de lo retratado) contrasta notablemente con esas otras imágenes que el profesional toma momentos antes de proceder al análisis, frívolas, simuladas. En ellas, destinadas a seducir, a atraer probablemente con algún fin comercial, una joven modelo, operada con el mismo objetivo, posa ante la cámara, finge las actitudes que el hombre le dicta: "que se recogiera el pelo de determinada forma, que mirara a la izquierda, que cruzara las piernas, que torciera los labios y luego que se los mordiera, que aparentara una seriedad que en aquel momento estaba ausente en ella" (Barrientos, Una casa en llamas). En esta sesión fotográfica se constata esa relación sospechosa entre el arte y la verdad de la que habla Susan Sontag (19), mientras que las imágenes enviadas de manera anónima son, una vez descartadas las dudas, una "prueba incontrovertible de que sucedió algo determinado" (Sontag 19).

Convencido de la autenticidad de las imágenes y ante la imposibilidad de descubrir quién y con qué intención se las ha enviado a su tía, el protagonista resuelve quemar las fotografías y mentir a su familia acerca del dictamen de su amigo experto. Para quienes son presentadas como una ficción carecen de cualquier valor y, entonces, pueden ser desechadas sin reparos. Sin embargo, el protagonista, que conoce la verdad, decide liberar a la familia de ese sufrimiento provocado por el macabro envío desechando la evidencia de un crimen, aunque ello pueda implicar un delito de obstrucción a la justicia y sin considerar, por otra parte, la posible existencia de otras copias, puesto que no está en poder de los negativos originales. 
La fotografía, junto con la grabación fílmica, aparece en los textos de Barrientos también como un potente testigo de la historia del país y de las historias personales de sus habitantes. Si, por un lado, las fotografías se constituyen como vestigios de un mundo y unas vidas anteriores a la guerra que se desata en la Bolivia distópica de En el cuerpo una voz, la grabación busca recoger testimonios del mencionado conflicto, con el objetivo de reconstruir el pasado reciente, de suplantar la ausencia de imágenes, de "armar una memoria colectiva, un mural de voces". Para ello, por encargo del recién creado Ministerio de Cultura, el protagonista y su ayudante recorren distintas comunas del norte del departamento de Santa Cruz, entrevistando y grabando a los supervivientes del "colapso".

En varios de estos encuentros, los entrevistados les enseñan a estos dos recopiladores fotografías tomadas antes de la guerra. Aparecen retratados en ellas, pero ya no son los mismos: otros rostros, otras actitudes... El cambio que puede apreciarse entre la imagen y la realidad presente se debe no solo al paso del tiempo, sino a la experiencia vivida, traumática.

Asimismo, en ese contexto convulso, que culmina con una transformación radical de la realidad política nacional, la fotografía puede, justamente en virtud de ese poder testimonial antes mencionado, usarse ilícitamente, como un medio de suplantar una identidad, de fingir, de apropiarse de una vida ajena. Así se constata en una de las entrevistas filmadas, que confiesa haber matado a un oficial de la brigada falangista:

Revisé sus bolsillos y encontré una foto de su mujer. Era choca, pelo corto, de unos veintisiete. No parecía camba: alemana o gringa, de por allá. Siempre la llevaba conmigo y se la mostraba a otros. Mentía, les decía que en esa otra vida que todos tuvimos antes de que nos reclutaran a la fuerza, ella era mi esposa. [...] Cada vez que inventaba esa historia le ponía el mismo nombre: Alicia, les decía que el nombre de mi mujer era Alicia (Barrientos, En el cuerpo).

En la novela Hoteles aparece nuevamente un interés por las entrevistas grabadas, esta vez por parte de un estudiante que desea realizar un documental sobre el particular viaje que durante dos meses realizan por carretera, en un viejo Chrysler Imperial, una pareja y la hija de ella. Con la cámara y las preguntas, el joven director quiere averiguar los motivos que les llevaron a emprender esta aventura, los detalles de la misma, las distintas impresiones y sensaciones que suscita en sus protagonistas. Se trata, en definitiva, de suplir, una vez más, la ausencia de imágenes; de un intento por hacer perdurar un 
viaje que, de otra manera, no existiría más que en el recuerdo de quienes lo vivieron: "No tengo ninguna imagen [...]. No hay ningún registro, el viaje desapareció por completo. [...] Fantaseo con llevar la cámara y filmar lo que quedó del Chrysler, los restos, algo muerto y hermoso. Nadie podrá decodificar el pasado que contiene"4 (Barrientos, Hoteles 17).

Aunque la fotografía no desempeña un papel tan relevante desde el punto de vista argumental como en otros textos, aparece, no obstante, en varias ocasiones a lo largo del relato, como documento físico o potencial al que aluden los personajes. Como ejemplo de este primer caso, destacan las fotos de una mujer desnuda que descubren entre las páginas de una Biblia, en el cajón de la mesilla de noche de una de las muchas habitaciones de hotel en que pernoctan. Estas imágenes, especialmente debido a la actitud y apariencia de la mujer retratada, implican la intrusión de otra vida, también anónima, en las suyas, en tanto que vulneran en cierta medida el aislamiento y la privacidad que caracterizan a este tipo de espacios. Como ejemplo del segundo caso, la niña, que constantemente imagina un futuro apocalíptico quizá sugerido por los parajes desérticos que recorren, alude a la imposibilidad de registrar a través de la fotografía, una vez que la raza humana haya desaparecido, los efectos de la guerra, no exentos de belleza: "Los colores del cielo cuando las bombas estallen, decía la niña. Nadie va a estar vivo para sacar fotos de eso tan lindo" (Barrientos, Hoteles 10).

En cambio, desde el prisma discursivo, la fotografía adquiere una relevancia notoria. Los recuerdos de los personajes, a menudo comparados por ellos mismos con instantáneas, son en efecto imágenes que captan momentos concretos, y todo ello determina en alto grado el ritmo y el estilo de la narración, aspecto que retomaré más adelante: "Una polaroid. Tres personas: el padre, la madre y el niño. Todo mi mundo conocido no hubiera sido posible si no me hubiera ido. Todas las fugas son quiebras de la identidad. La gente se mete en el auto y conduce, deja calles. Se cuenta historias. Se facilita las cosas" (Barrientos, Hoteles 55).

En la novela La desaparición del paisaje, las fotografías cumplen un papel decisivo en la recuperación por parte del protagonista, que regresa a Bolivia tras más de diez años en EE.UU. sin contacto alguno con sus parientes y amigos, de su propio pasado (su infancia, su adolescencia...) y del de sus padres, ya fallecidos. Como todo bien preciado, algunos personajes 
las conservan con celo, sobre todo aquellas que retratan momentos felices. A este respecto, resultan significativas las palabras de Susan Sontag (23) acerca del álbum familiar:

Mediante las fotografías cada familia construye una crónica-retrato de sí misma, un estuche de imágenes portátiles que rinde testimonio de la firmeza de sus lazos. [...] La fotografía se transforma en rito de la vida familiar justo cuando la institución misma de familia [...] empieza a someterse a una operación quirúrgica radical. A medida que esa unidad claustrofóbica, el núcleo familiar, se extirpaba de un conjunto familiar mucho más vasto, la fotografía acompañaba para conmemorar y restablecer simbólicamente la continuidad amenazada y el ocaso del carácter extendido de la vida familiar. Estas huellas espectrales, las fotografías, constituyen la presencia vicaria de los parientes dispersos.

Junto con los objetos personales, las fotografías forman parte de la memoria familiar, una memoria que se concentra fundamentalmente en torno a la casa donde creció, ahora habitada solo por la segunda mujer de su padre. Todo ese legado lo convierte en un espacio un tanto opresivo, por cuanto concita en el personaje sentimientos dolorosos. Cuando, años más tarde y tras la muerte de su última habitante, el protagonista y su hermana deciden venderla, recurren nuevamente a la fotografía para inmortalizarla:

En los días que siguieron empaquetamos las pertenencias de María $\mathrm{y}$ de mi padre, y pusimos un anuncio en el periódico para anunciar la venta de la casa. Recorrí con Fabia las habitaciones por última vez. Me pidió que le tomara una foto en el que entonces había sido su cuarto, un espacio que comenzaba a vaciarse de nuestra historia (Barrientos, La desaparición 224).

Por otra parte, las fotografías recientes constituyen un medio a través del cual se pueden actualizar los rostros de ese pasado. El protagonista allana la casa de una antigua compañera de colegio, la espía y la fotografía, penetrando así en su privacidad, descubriendo cómo son su vida y su aspecto actuales. Pero el verdadero propósito de estas fotos es inducir al recuerdo y atormentar al hombre que la violó muchos años atrás. El protagonista y un amigo lo localizan, lo siguen y, tras propinarle una seria paliza, le muestran el rostro de su víctima para enfrentarlo con el acto que cometió, del que ellos fueron testigos accidentales y pasivos. En este acto de violencia física y psicológica 
con el que pretenden a un tiempo condenar al violador y expiar su propia culpa, la imagen habría de actuar como detonante, como catalizador del recuerdo del delito y del arrepentimiento. Sin embargo, los cambios físicos operados por el paso del tiempo impiden que esta tenga los efectos esperados:

[...] Jalé su pelo y lo obligué a que mirara a la cámara.

Allí estaba ella, acabando la copa de vino, con la mirada fija en alguna parte de su casa.

Una mujer cansada después de un día cualquiera en el trabajo.

Mirá bien, dijo Alberto.

[...] Intentaba comprender qué sucedía, pero no conseguía unir los fragmentos.

¿Qué?, dijo jadeando.

Alberto me miró y se acercó aún más, sostuvo con fuerza la barbilla del ex jugador y lo obligó a mirar con más atención.

Mirá bien, repitió, pero no la reconocía. En la fotografía Adriana era ya una mujer, cuando la violó era una muchacha. No se trataba de la misma persona, pero Alberto necesitaba que lo fueran, que coincidieran en ese momento (Barrientos, La desaparición 47-48).

Antes de pasar al análisis de los relatos que conforman el corpus principal del presente trabajo, cabe destacar que esta novela de Barrientos pone de manifiesto un fenómeno global como es el de las redes sociales, en el que la fotografía desempeña un papel determinante. Así, uno de los personajes, a través de las imágenes subidas a la red mediante este tipo de herramientas, expone de manera voluntaria su privacidad. Frente a la trascendencia de las imágenes tanto en el argumento de sus textos como en la poética que subyace a todos ellos, la banalidad de estas otras fotografías tomadas con dispositivos móviles con el objetivo de exhibir una felicidad no siempre real entronca a la perfección con el retrato de la sociedad cruceña que el autor realiza en sus textos, en especial de su propia generación, a la que pertenecen también los protagonistas de buena parte de sus ficciones. En él impera la apariencia: casas de ensueño, fiestas, ropa de marca, aficiones caras... que las fotos registran y muestran a los demás pero que disfrazan en la mayoría de los casos carencias afectivas, fracasos profesionales o emocionales, complejos. 


\section{LA FOTOGRAFÍA EN FOTOS TUYAS CUANDO EMPIEZAS A ENVEJECER: DE MOTIVO ARGUMENTAL A ESTILO NARRATIVO}

Fotos tuyas cuando empiezas a envejecer se compone de cinco relatos en los que la fotografía y el cine actúan como hilo conductor. Independientemente de su mayor o menor trascendencia en la trama concreta de cada una de las narraciones, son elementos estructuradores del volumen que participan de consideraciones metaliterarias o metartísticas y/o bien de reflexiones acerca del tiempo y la fugacidad de la existencia. En las ficciones de Barrientos, la fotografía es, al igual que el cine ${ }^{5}$, la literatura o la música, un medio a través del que es posible consignar, al menos parcialmente, ciertas vivencias. Los personajes a menudo se interrogan acerca de las posibilidades que esto genera: ¿es posible perdurar gracias a las imágenes o la escritura?, ¿volver a ver detenidamente grabaciones o fotos permitirá comprender mejor qué sucedió o por qué se actuó de una determinada manera en los momentos capturados?, ¿sería posible grabar toda una vida y acceder a todo lo que la memoria no puede retener?, ¿alguna de estas artes tiene en realidad algo que ver con la verdadera existencia?

En el relato inaugural de la obra, titulado "Primeras canciones", un narrador omnisciente en tercera persona presenta distintos instantes de la vida de dos personas, instantes que pertenecen a marcos temporales diferentes y en ocasiones también distantes. Lo interesante, desde el prisma de este trabajo, es que son presentados como si tanto el narrador como los lectores pudieran ver directamente las imágenes descritas, registradas por una hipotética cámara de seguridad: "Si hubiera una cámara de seguridad en el baño se los vería desnudos. Chicos recién salidos de colegio, él tiene dieciocho, ella diecinueve [...] Él está de pie, la observa. Ella dice algo, él se acerca" (Barrientos, Fotos tuyas 11). La cámara no existe, como reconoce el propio narrador, $\mathrm{y}$, por ende, tampoco las imágenes como tal, pero sí aquellas que se construyen discursivamente. La voz narrativa, al tiempo que emplea con insistencia el imperativo ("véanlos", "mírenlos", "véanlo", "mírenla"), que remite al presente

La relación de Maximiliano Barrientos con el séptimo arte es también reseñable. Además de ser crítico de cine y de impartir talleres de esta disciplina, ha trabajado el guion, por ejemplo, adaptando uno de sus cuentos literarios al lenguaje cinematográfico para que pudiera ser, a su vez, convertido en cómic por Carol Thompson El cuento original, el guion y el cómic pueden consultarse en la siguiente página: $h t t p: / /$ thestudio.uiowa.edu/iowa-literaria/?p=1530 
de ese supuesto visionado, a lo que se estaría desarrollando en la pantalla, anticipa sucesos futuros, modificando así la percepción de ese "presente":

Véanlos a todos en el principio de la borrachera entrando en el boliche donde tocarán Saúl y Rafael con un grupo de universitarios con los que terminarán peleándose esa misma noche. Vean a esos chicos y piensen nuevamente en el año: 1999. Muchos comienzan la universidad, tienen miedo pero encuentran los mecanismos necesarios para atenuarlo. Entran y salen de la vida de otras personas a distintas velocidades produciendo todo tipo de heridas, pero ahora están donde deberían estar [...].

Mírenlos a todos, las cosas cambiarán para muchos, nadie lo sabe. No hay nada especial en estos cambios: el padre de alguno tendrá enfisema. Una madre se irá a vivir con el amante. Alguien dejará la universidad, se casará demasiado joven con la mujer que está mirando en este momento y ya nunca la verá como ahora lo está haciendo (Barrientos, Fotos tuyas 19-21).

Pese a haber confirmado la inexistencia de la cámara, el narrador sigue jugando con esa posibilidad y prolonga el juego hasta el punto de imaginar un futuro en que, desde distintos lugares del mundo, los personajes ven su propia vida, repasando las grabaciones, tratando de reconocerse en quienes fueron diez años atrás, adelantando "las partes devastadoras porque esta clase de videos sirve para demostrar que las vidas se hacen pedazos a distintas velocidades. Que las personas que amamos dejan de ser jóvenes" (Barrientos, Fotos tuyas 24). Se pregunta el narrador acerca de las reacciones que tendrían si esto fuese posible, en qué se fijarían, cómo podrían soportarlo. Esta posibilidad se presenta como un medio para solventar la arbitrariedad del recuerdo, de una memoria que conserva determinados momentos y otros no, independientemente de su importancia. Pero una y otra vez se niega la existencia de registros, en una paradoja que se instaura con el propio acto de escritura: "No existe nada que testimonie quiénes son" (Barrientos, Fotos tuyas 36).

El testimonio textual se confirma por cuanto se duplica: al final del relato se produce un desdoblamiento de la narración, que se desarrolla, además de en el cuerpo principal, en una nota al pie que se extiende varias páginas. Este desdoblamiento implica una bifurcación temporal. Mientras que la narración principal se concentra en el presente, en el comienzo de la relación entre los dos protagonistas, la que discurre al pie de página se sitúa unos años más tarde, cuando esta está a punto de romperse. 
El recurso de la cámara se asemeja al empleado por Mario Benedetti en el relato "Para objetos solamente", de la obra La muerte y otras sorpresas, de 1968, en cuyo comienzo apunta a una posibilidad que, como en el caso de "Primeras canciones", no se consuma, si bien sus efectos llegan igualmente al receptor gracias a la descripción del narrador: "Por el momento nadie entra en la habitación, pero, si alguien entrara, o, mejor aún, si sólo penetrara una mirada, sin tacto, sin gusto, sin olfato, sin oído, sólo una mirada, y decidiera fríamente hacer un ordenado inventario visual de sus objetos, comenzando, digamos, por la derecha, lo primero que habría de encontrar sería [...]" (Benedetti 90). En el texto del escritor boliviano, esa objetividad de la mirada, cámara en este caso, está totalmente ausente. La voz narrativa selecciona qué momentos de las vidas susceptibles de ser filmadas llegan al lector y cuáles no. Se trata de una sucesión de momentos o incluso instantes, más cercana a la discontinuidad de un álbum fotográfico en el que las imágenes están dispuestas caprichosamente que a una filmación continuada. Por otro lado, la parquedad en las descripciones, que como se ha adelantado es común a todas las ficciones de Barrientos, se aleja del "ordenado inventario" del uruguayo y de su minuciosidad.

Las narraciones del escritor cruceño se caracterizan por su concisión. No tienen por objetivo abarcar historias, sino fragmentos de esas historias. A Barrientos le interesan los instantes detenidos y su estilo discursivo está muy influido por ello. Sus descripciones y narraciones no son sino pequeñas pinceladas, construidas con frases cortas, que prescinden de ornamentos retóricos y también, por lo común, del empleo de conectores que las enlacen entre sí. Así se logra un ritmo rápido, un estilo directo y conciso. La narración fotográfica no se sustenta por tanto en el detallismo de las descripciones, sino en un intento por capturar el instante.

Afirma Ansón (Novelas 45) que "el verdadero alcance de la fotografía [...], el compromiso más radical de la literatura también, va más allá de un propósito documentalista para adentrarse en los aspectos más descoloridos y triviales de la existencia". En determinados puntos de esas existencias muchas veces triviales y descoloridas recalan los textos de Barrientos. En Fotos tuyas cuando empiezas a envejecer la mayor parte de esos momentos tiene que ver con comienzos y finales, sea de etapas de la vida de los personajes, sea de las relaciones que establecen con otros. Así sucede, por ejemplo, en el relato de menor extensión del volumen, "Suerte", que vuelve sobre tres momentos clave de la relación entre dos jóvenes: el comienzo, la ruptura y un encuentro casual varios años después. "Los adioses" y su continuación, "Las 
horas", son narrados cada uno de ellos desde la perspectiva de uno de sus dos protagonistas. Mientras que el primero aborda la relación extramatrimonial entre Raquel y Sebastián, focalizando tan solo determinados instantes (algunas conversaciones, algunos encuentros), el segundo se centra en un día de la vida de ella, junto a su marido, su hija y embarazada de nuevo, años más tarde de que la aventura llegara a su término.

En estos relatos volvemos a encontrar el estilo de impronta fotográfica de "Primeras canciones". Ello se evidencia en "Las horas", donde los numerosos ejemplos de textualización de imágenes no fotográficas guardan una evidente semejanza con la descripción con la que comienza el relato, que sí corresponde a una fotografía (una de las muchas mencionadas a lo largo del relato), tomada por el marido de Raquel desde una avioneta en la zona de Beni, en Bolivia: "Una lengua de tierra cercada por agua. Animales muertos. Vacas, caballos. Un niño mira algo que es imposible determinar. Un reflejo de sol, un cuerpo de persona o de animal flotando, los restos de un auto. A unos metros, una casa prácticamente sumergida: sólo es visible el techo, parte de una chimenea rústica" (Barrientos, Fotos tuyas 107). La misma dinámica que estas líneas siguen otros fragmentos del cuento en los que la narradora protagonista atrapa distintos instantes: el particular modo en que la luz incide sobre los cuerpos o los objetos, la tonalidad de un determinado momento del día, la quietud de la noche, los movimientos de su hija durante el baño en una piscina.

Pero el ejemplo quizá más claro en este sentido sea justamente el del cuento que da título a la obra, "Fotos tuyas cuando empiezas a envejecer", cuyo narrador se apoya constantemente en fotografías a la hora de reconstruir la historia de Ingrid. Se trata, como en los casos anteriores, no de una historia lineal sino en un conjunto de sucesos, de momentos, de hitos en el transcurso de su amistad, desde que el narrador la conoce hasta el presente. Así, en la construcción del relato alternan las descripciones de estos documentos visuales con los propios recuerdos del narrador, sin que existan apenas diferencias desde el punto de vista discursivo entre unas y otros. Al final del relato, cuando el narrador se refiere a una parte de la vida de Ingrid que no ha presenciado y de la que no hay ningún registro fotográfico, esto es, cuando ya no dispone de imágenes ni mentales ni materiales, tiene que inventarlas y lo hace a través de las palabras:

No sé cómo lucía mi amiga montada en la estatua de ese viejo y desconocido prócer. A veces quiero creer que estaba hermosa a pesar 
de la borrachera y la tristeza y de todas las noches de desvelo. Quiero creer que hizo las paces consigo misma durante esa hora tan temprana de la mañana. Quiero creer que dejó de lado las recriminaciones, las enterró en los restos de lo que ella era, de lo que podía volver a ser algún día.

[....] Quizá no quiso hacer ninguna de estas cosas, sólo quedarse quieta ahí durante unos minutos, en una plaza donde no había nadie y donde el sol estaba fuerte y bañaba su pelo y sus hombros (Barrientos, Fotos tuyas 71).

A este respecto de la narración fotográfica, resultan significativos los paralelismos entre el cuento y la fotografía que Julio Cortázar establece en "Algunos aspectos del cuento". El escritor argentino realiza una comparación entre novela y cuento, asimilando ambos géneros, respectivamente, al cine y a la fotografía. La analogía entre las novelas y las películas se sustenta en que ambas constituyen un "orden abierto", mientras que la fotografía, como el cuento, son por naturaleza limitados, por cuanto "recortan" un fragmento de una realidad mucho más amplia:

Mientras en el cine, como en la novela, la captación de esa realidad más amplia y multiforme se logra mediante el desarrollo de elementos parciales, acumulativos, que no excluyen, por supuesto, una síntesis que dé el clímax de la obra, en una fotografía o en un cuento de gran calidad se procede inversamente, es decir, que el fotógrafo o el cuentista se ven precisados a escoger y limitar una imagen o un acaecimiento que sean significativos, que no solamente valgan por sí mismos, sino que sean capaces de actuar en el espectador o en el lector como una especie de apertura, de fermento que proyecta la inteligencia y la sensibilidad hacia algo que va mucho más allá de la anécdota visual o literaria contenidas en la foto o en el cuento (Cortázar 406).

Este fenómeno está efectivamente presente en las ficciones de Barrientos, si bien en su caso no es exclusivo de los cuentos. Sus novelas, pese a su mayor extensión, mantienen esa economía en el empleo de imágenes y esa síntesis lingüística que, como ha señalado López Suárez (115), caracterizan la narración fotográfica. En Hoteles, por ejemplo, la manera en que se reconstruye el viaje por parte de sus tres protagonistas, el relato que hacen ante la cámara de su experiencia, así como el discurso del director del documental destacan por su indeterminación y por su fragmentariedad. 
En cuanto a lo primero, apenas se aportan detalles concretos relativos al recorrido, los lugares visitados, los alojamientos, la motivación u objetivos que llevan a emprender el periplo, etc. El receptor de la obra, al igual que el documentalista interesado en comprender el objetivo y los resultados de ese viaje, no hallará más que respuestas parciales. A ello contribuye el segundo de los aspectos señalados, su carácter fragmentario. Los ocho capítulos de la novela se componen de uno o de varios fragmentos correspondientes a distintas voces en primera persona: las de los tres protagonistas del viaje y la del propio director. Los personajes no refieren su experiencia a través de un relato lineal, ordenado y detallado. Ello viene impuesto, en parte, por el propio formato del documental, que consiste en varias entrevistas a los tres "viajeros", realizadas en distintas sesiones y dispuestas de manera intercalada en la novela.

Como consecuencia de lo anterior, el viaje, tal y como llega a los lectores, es un conjunto de imágenes procedentes de recuerdos aislados que no respetan el orden cronológico en que tuvieron lugar los hechos, una sucesión de instantáneas registradas en la memoria de cada uno de los tres protagonistas, que estos tratan de comunicar con un lenguaje sencillo y parco, con frases cortas pero concisas y a menudo incisivas. Así, los miles de kilómetros recorridos se condensan en un conjunto de fotografías mentales del paisaje registradas en el camino: carreteras llenas de tierra y polvo, cadáveres de animales en la calzada, estaciones de servicio, pueblos o caseríos, de cuando en cuando alguna ciudad, parajes desérticos, hoteles de paso, etc.

De hecho, la concepción de Tero, uno de los protagonistas, sobre el viaje, se basa precisamente en la imagen -subjetiva- y en el fragmento: "Viajamos para formar imágenes. Viajar es construir un paisaje privado, una colección de espacios mutantes: ciudades que son fragmentos de muchas ciudades" (Barrientos, Fotos tuyas 22). En un sentido similar apuntan las reflexiones del joven documentalista acerca de su propio trabajo, que pueden ser interpretadas en clave metatextual, como una manifestación de la poética del propio Barrientos, constatables en esta novela y en el estilo y el lenguaje mayoritariamente empleados en el resto de su producción: "Me interesa que los relaten en tiempo presente. Crónicas mínimas, ideas sueltas. El relato como un collage de impresiones" (Barrientos, Hoteles 41$)^{6}$. 
Volviendo a Fotos tuyas cuando empiezas a envejecer, el mismo título alude a uno de los temas predilectos de la narrativa de Barrientos, estrechamente relacionado con la fotografía: el paso del tiempo. Los personajes de estos cinco relatos, que se hallan entre el final de la juventud y el comienzo de la madurez, son conscientes del carácter transitorio del presente. La función de la fotografía es justamente capturar algunas de esas vivencias, hacer que perduren en ese transcurrir implacable del tiempo. Los protagonistas de Barrientos reconocen, por tanto, la "fuerza" de la fotografía, que según Carrillo Rubio (18) reside "en su capacidad para detener en el tiempo un hecho producido en un momento y lugar determinados".

Fotografiarse, registrar ciertas experiencias, implica para los personajes "uma sensação de vitória contra um dos fenômenos mais misteriosos da vida: o tempo" (Fonseca 151), puesto que, como señala Barthes (26), la fotografía repite de forma mecánica aquello que ya no podrá repetirse jamás existencialmente. Asimismo, les proporciona un refugio, en tanto que les permite instalarse, mediante la contemplación de las imágenes, en los momentos felices que estas retratan. Así lo ha señalado González Almada, estudiosa de la obra de Barrientos: "la fotografía [...] representa un deseo, la intención de congelar un momento feliz que existió o bien que es imaginado, un ansia por conservar, preservar materialmente" (155). Este tipo de imágenes constituye una excepción en la fugacidad en que se instauran los personajes, una fugacidad que no viene determinada únicamente por factores externos e inevitables, sino por su propia condición de "fugitivos", de seres en continuo tránsito (González Almada 165). Frente a los espacios temporales y proclives al anonimato que los personajes de Barrientos suelen frecuentar (hoteles, bares, centros comerciales...), las fotografías se presentan como espacios estables, permanentes, atemporales y por lo común portadores de una fuerte carga emotiva.

La relación entre fotografía y tiempo y los consecuentes binomios dinamismo/estatismo y fugacidad/permanencia se manifiestan en otras obras del escritor boliviano. Por ejemplo, en la novela La desaparición del paisaje, donde se afirma, a propósito de los recuerdos y de las fotografías, imágenes mentales y materiales del pasado: "La vida no trata del deterioro de esas imágenes, la vida trata de cómo envejecemos y esas imágenes se mantienen fijas, incontaminadas, protegidas de nuestros propios cuerpos, de la marcha silenciosa de las enfermedades" (Barrientos 54). Estas líneas apuntan a lo señalado por Ansón a propósito de la capacidad de la fotografía para preservar los cuerpos o, mejor dicho, su imagen, del deterioro, de la 
degradación que imponen la enfermedad y la muerte: "en el retrato proyectamos nuestra realidad física en una imagen para salvaguardar nuestra identidad, para salvarla y luchar contra la disolución del Yo en el aniquilamiento, en la inexcusable disolución temporal que la imagen fotográfica impone cada vez que nos dejamos fotografiar" (Ansón, Novelas 85).

En este contexto, la fotografía se relaciona con otros medios y otras disciplinas capaces de conservar, con mayor o menor precisión, parte de ese presente efímero. Las referencias al cine -o, simplemente, a la filmación-, a la música y, en menor medida, a la pintura como medios de conservación son recurrentes. Algunos personajes fantasean con la posibilidad de ser una canción, de vivir en una canción o en una película y, de este modo, perdurar o hacer perdurar ciertos momentos, al tiempo que se evaden de sus propias circunstancias. Un ejemplo de ello se puede encontrar en el relato "Las horas", donde Raquel, cuando termina de leer un fragmento de la novela de Michael Cunningham, piensa al observar a su hija en la piscina en un particular instante de su vida (una edad que no volverá a repetirse) y del día (una luz característica): "en una novela o en una película o en una canción tan potente como esta mañana (que la contenga, que la reproduzca), la segunda mañana de sus cuatro años" (Barrientos, Fotos tuyas 115).

En las conversaciones entre Susy y Sebastián en el relato "Los adioses", es la música el arte elegida no solo como un medio de conservación, sino también como un espacio alternativo, un mundo paralelo:

¿Alguna vez has escuchado "Happy together”?, pregunta Susy.

Sí, contesta Sebastián.

Me gustaría vivir en esa canción.

¿Por qué?

Porque no creo en Dios (Barrientos, Fotos tuyas 95-96).

A la posibilidad de vivir en una canción se suma la de hacerlo en una película y, más aún, en una simple grabación: "Yo quisiera vivir en la cámara de seguridad de una gasolinera", afirma Sebastián (Barrientos 96).

Asimismo, registrarse mediante alguno de estos medios proporcionaría a los personajes la posibilidad de observarse objetivamente, de mirarse desde fuera de sí mismos, como si de una tercera persona se tratase. "La fotografía revela, hace visible lo que hasta entonces permanecía ignorado", afirma Ansón (Novelas 83). La obsesión de los personajes de Barrientos por la fotografía y otras modalidades de registro de la experiencia podría residir en una necesidad 
de objetivarse para comprenderse, en la posibilidad de que, observando su vida desde fuera, como lo haría un espectador, adopte el sentido del que carece para ellos. En este sentido, algunos personajes expresan curiosidad acerca de cómo será su vida vista por otros, o por ellos mismos, desde otra perspectiva, en otro tiempo.

Si bien en "Los adioses" se afirma que "las fotos no tratan de la vida, no capturan la vida" (Barrientos, Fotos tuyas 91), lo cierto es que los personajes de Barrientos son conscientes de que el instante capturado, "que se perdió en ese continuo que es la realidad, termina por convertirse en una instantánea intemporal al ser recogido por la cámara, permitiéndonos así contemplarla y repensarla tantas veces como consideremos" (Carrillo Rubio 18). De hecho, en ese mismo relato, en la nota al pie que precede a la citada afirmación, el escritor del relato del cuerpo principal explora la posibilidad de filmar su propia vida, lo que implicaría una interpretación por parte de los demás y por sí mismo: “¿Qué momentos trabajaría mejor? ¿En cuáles haría énfasis? [...] ¿Cómo retrataría esos momentos? ¿Cómo me descifrarían los otros?” (Barrientos 90). Aunque en este caso se trata de una filmación y no de fotografías, aquello que el protagonista afirma querer registrar es en efecto un conjunto de imágenes, retenidas por su memoria y condensadas a través de la escritura que es, a la postre, la forma de conservación elegida:

Filmar los momentos importantes. Verme crecer. Verme saliendo de promoción con mis compañeros. Verme haciendo el amor por primera vez. Verme discutiendo con Margot. Verme sentado al lado de $\mathrm{V}$ en su auto al final de la tarde. Filmar mi vida en vez de llevar un diario, en vez de escribir cuentos en mi diario. Dividirla por categorías: Aquí comenzó mi adolescencia y en este preciso momento acabó. Catalogar los acontecimientos que determinaron los cambios, los desplazamientos. Filmar borracheras. Filmar letreros y gasolineras. Cines abandonados. Ancianos locos y desnudos haciendo autostop. Filmar a mis padres dormidos. Hacer de mi vida una película, archivarla, editarla. Sebastián como cámara de seguridad que permite verme por fuera, como si fuera otra persona (Barrientos 98).

Sebastián, es decir, el personaje que él construye mediante la creación literaria es quien posibilita a este escritor, a modo de alter ego, "filmarse" y "observarse". Las reflexiones sobre la fotografía, el cine o la música confluyen, finalmente, en una reflexión en torno a la escritura, a la literatura, concebida como "forma de conservación, como museo" (Barrientos 84). 


\section{CONSIDERACIONES FINALES}

La impronta de la fotografía es evidente en los textos de Maximiliano Barrientos, tanto en su escritura a base de imágenes como en la temática y los personajes. Su narrativa se instaura en el instante. Su estilo narrativo viene determinado por la condensación, con un lenguaje directo y parco en detalles y en adornos, de determinados momentos de la vida de los personajes. Estos, conscientes de la fugacidad de la vida, optan por el tránsito constante, refugiándose en no-lugares, en espacios de transición y de anonimato, en la posibilidad -constantemente aludida cuando no puesta en práctica- de una huida. No obstante, encuentran en la fotografía, como también en otras artes, una suerte de refugio ante el paso del tiempo, el olvido y la intrascendencia con la que parecen transcurrir sus vidas.

Además, en los textos de este autor, las consideraciones acerca de la fotografía se enmarcan por lo común en una reflexión más amplia sobre de la capacidad de determinados medios - la cinematografía, la música, pero sobre todo la literatura- para registrar vivencias, para dar cuenta de ellas. En consecuencia, cada uno de los relatos que componen Fotos tuyas cuando empiezas a envejecer es un intento por captar instantes que nunca volverán a repetirse. Se juega con la posibilidad de registrar la existencia y se niega al tiempo que se consigna mediante la escritura, en imágenes formadas con palabras. La fugacidad detenida que representa la fotografía y su poder evocador, a partir del fragmento, en el receptor son el objetivo y principal logro de estos relatos.

\section{BIBLIOGRAFÍA}

Ansón, Antonio. Novelas como álbumes. Fotografia y literatura. Murcia: Mestizo, 2000. "Influencia de la fotografía en la literatura española y latinoamericana". ARBOR. Ciencia, Pensamiento y Cultura CLXXXVI 741 (2010): 153-162.

"Fotografía y literatura: manual de instrucciones". Ínsula 864. Monográfico

"Literatura y fotografía" (2018): 4-8.

Barrientos, Maximiliano. Fotos tuyas cuando empiezas a envejecer. Cáceres: Periférica, 2011. Hoteles. Cáceres: Periférica, 2011. La desaparición del paisaje. Cáceres: Periférica, 2015. Una casa en llamas. Buenos Aires: Eterna Cadencia, 2015. En el cuerpo una voz. Ciudad de México: Almadía Ediciones, 2018. Ebook. 
Barthes, Roland. La cámara lúcida. Nota sobre la fotografía. Barcelona: Paidós, 2011.

Benedetti, Mario. La muerte y otras sorpresas. México D.F.: Siglo XXI, 1969.

Carriedo, Lourdes y Anne-Marie Reboul. "Introducción. En torno al diálogo intermedial”. Entre escritura e imagen II. Imágenes fijas, imágenes cinéticas. Bruxelles: Peter Lang, 2018. 9-22.

Carrillo Rubio, Pedro. "En busca de «un instante de verdad». Gente de libro". Ínsula 864. Monográfico "Literatura y fotografía" (2018): 16-19.

Cortázar, Julio. “Algunos aspectos del cuento”. Cuadernos Hispanoamericanos 255 (1971): 403-416.

Cunningham, David et al. "Introduction". Photography and Literature in the Twentieth Century. Cambridge: Cambridge Scholars Publisher, 2005. 1-9.

Fonseca, Pedro Carlos L. y Fábio d'Abadia de Sousa. "Literatura e fotografia: o anseio pela apreensão do instante". Signótica v. 20, n. 1 (2008): 149-174.

González Almada, Magdalena. Relaciones de poder, imaginarios sociales y prácticas identitarias en la narrativa boliviana contemporánea 2000-2010. Córdoba: Universidad Nacional de Córdoba, 2017.

López Suárez, Mercedes. "Fragmentos de una reflexión sobre literatura y fotografía". Cuadernos de Filología Italiana vol. 13 (2006): 97-118.

Louzao, Alicia. "Maximiliano Barrientos: «Latinoamérica ha sido un continente proclive a producir monstruos»". Ocultalit (04/07/2018). https://www.ocultalit.com/entrevistas/ maximiliano-barrientos-entrevista-en-el-cuerpo-una-voz-eterna-cadencia/

Montier, Jean-Pierre. "La photolittérature ou le commerce des regards". Entre escritura e imagen II. Imágenes fijas, imágenes cinéticas. Coord. Lourdes Carriedo y Anne-Marie Reboul. Bruxelles: Peter Lang, 2018. 25-42.

Olivier, Florence. "De algunos usos de la fotografía en la literatura hispanoamericana contemporánea”. Cuadernos de Literatura 20.40 (2016): 430-448.

Sontag, Susan. Sobre la fotografía. Madrid: Alfaguara, 2007. 